\title{
PENGARUH PENAMBAHAN ASAP CAIR TERHADAP SIFAT KIMIA DAN SENSORIS TELUR ASIN RASA ASAP
}

\section{THE EFFECT OF LIQUID SMOKE ON CHEMICAL AND SENSORY PROPERTIES OF SMOKED SALTED EGG}

\author{
Asri Nursiwi ${ }^{1)}$, Purnama Darmadji ${ }^{2)}$, Sri Kanoni ${ }^{2)}$ \\ 1) Jurusan Ilmu dan Teknologi Pangan, Fakultas Pertanian, Universitas Sebelas Maret \\ J1. Ir. Sutami No 36 A Kentingan Surakarta 57126 \\ ${ }^{2)}$ Jurusan Teknologi Pangan dan Hasil Pertanian, Fakultas Teknologi Pertanian, Universitas Gadjah Mada \\ Jl. Sosio Yustisia, Bulaksumur, Yogyakarta 55281 \\ Email: asrinursiwi@gmail.com
}

\section{ABSTRACT}

Salted egg is an egg product that made by salting. The flavor of salted egg is salty. On salted egg, stinking odour appeared repeatedly caused by the process of salting is not optimal. The research tried to develop the flavor of salted egg by making smoked salted egg to solve the problem. The smoked flavor obtained by adding liquid smoke.The objective of the research was to investigate the change in chemical properties of duck egg during brining in saline at different times and different concentration of liquid smoke. The research was conducted by adding liquid smoke at concentration $0 \%, 0,5 \%$, dan $1 \%(v / v)$ in the 30\% (w/v) saline solution. At day $8^{\text {th }}, 10 t^{h}$, and $12^{\text {th }}$ the egg were analyzed for moisture, salt, lipid, and protein contents. Sensory analysis used hedonic test with 20 panelist. The research showed that during brining in the saline solution with liquid smoke, moisture, salt, and protein content changed but fat content did not changed. The egg obtained by adding liquid smoke at concentration $5 \%(\mathrm{v} / \mathrm{v})$ and 8 days brining in saline solution was the most acceptable by panelist.

Key words : salted egg, liquid smoke, smoked salted egg

\begin{abstract}
ABSTRAK
Telur asin merupakan produk hasil olahan telur yang diperoleh dengan cara penggaraman. Citarasa yang muncul dari telur asin selama ini hanya asin. Selain itu pada telur asin masih sering tercium bau amis dan bau busuk yang disebabkan karena tidak optimalnya proses penggaraman. Untuk mengatasi permasalahan tersebut maka pada penelitian ini dikembangkan pembuatan telur asin rasa asap yang dihasilkan dengan penambahan asap cair. Dalam penelitian ini dilihat perubahan kimia yang terjadi pada telur selama proses perendaman dalam larutan garam dengan penambahan asap cair. Penelitian dilakukan dengan penambahan asap cair pada konsentrasi $0 \%, 0,5 \%$, dan $1 \%(\mathrm{v} / \mathrm{v})$ dalam larutan garam $30 \%(\mathrm{~b} / \mathrm{v})$. Pada hari perendaman ke-8, 10 , dan 12 dilakukan analisa kadar air, kadar garam, kadar protein, dan kadar lemak. Selain itu juga dilakukan pengujian sensoris oleh 20 orang panelis untuk menilai tingkat kesukaan panelis terhadap sembilan sampel tersebut. Hasil penelitian menunjukkan bahwa selama proses perendaman telur dalam larutan garam dengan penambahan asap cair terjadi perubahan kadar air, kadar garam, dan kadar protein. Akan tetapi kadar lemak tidak mengalami perubahan. Telur asin yang dibuat dengan penambahan asap cair dengan konsentrasi $0,5 \%$ dan lama perendaman 8 hari merupakan telur asin yang paling disukai panelis.
\end{abstract}

Kata kunci : telur asin, asap cair, telur asin rasa asap

\section{PENDAHULUAN}

Telur merupakan salah satu sumber protein hewani. Telur memiliki rasa yang lezat dan bergizi tinggi. Telur mengandung protein $13,1 \%$, lemak 14,3\%, serta vitamin, dan mineral (Anonim, 1981). Akan tetapi telur merupakan bahan pangan yang mempunyai sifat mudah mengalami kerusakan, baik kerusakan alami, kimiawi maupun kerusakan akibat masuknya mikrobia melalui pori-pori telur. Kerusakan yang terjadi secara alami berupa pecah atau retak apabila terkena tekanan, pukulan, atau benturan. Kerusakan lain adalah akibat udara dalam isi telur keluar sehingga derajat keasaman naik. Sebab lain adalah karena keluarnya uap air dari dalam telur yang membuat berat telur turun serta putih telur encer sehingga kesegaran telur merosot. Kerusakan telur dapat pula disebabkan oleh masuknya mikroba ke dalam telur, yang terjadi ketika telur masih berada dalam tubuh induknya (Anonim, 2000).

Dengan kondisi yang demikian maka untuk memperpanjang masa simpan dari telur diperlukan pengawetan. Salah satu cara pengawetan yang bisa diterapkan adalah dengan penggaraman. Penambahan garam pada telur dalam jumlah tertentu dapat menaikkan tekanan osmotik yang 
menyebabkan plasmolisa pada sel mikroba, mengurangi daya kelarutan oksigen, menghambat kegiatan enzim proteolitik dan sifat garam yang hidroskopik menyebabkan Aw menurun (Sarwono, 1987). Selain dapat memperpanjang masa simpan, penggaraman juga akan menghasilkan telur asin dengan cita rasa spesifik.

Penggunaan telur itik dalam berbagai makanan tidak seluas telur ayam karena bau amisnya yang tajam. Selain baunya yang lebih amis, telur itik juga mempunyai poripori yang lebih besar sehingga baik untuk diolah menjadi telur asin (Marssy, 2007). Pada telur asin masih sering tercium bau amis maupun bau busuk. Hal ini bisa disebabkan karena tidak optimalnya proses penggaraman sehingga mikroorganisme di dalam telur masih bisa tumbuh. Untuk mengurangi kemungkinan terciumnya bau amis dan bau busuk ini maka pada proses penggaraman ditambahkan asap cair.

Asap cair adalah kondensat berair alami dari kayu yang telah mengalami aging dan filtrasi untuk memisahkan seyawa ter dan bahan-bahan tertentu (Pszczola,1995). Asap cair dibuat dari hasil pirolisis kayu atau dibuat dari campuran seyawa murni (asap buatan). Komponen asap cair harus dilarutkan dalam air atau pelarut organik atau dibawa oleh pengikat seperti bumbu, gula, tepung, garam, atau lemak ( Gorbatov et al., 1971).

Penambahan asap cair telah lama digunakan sebagai pengganti proses pengasapan konvensional. Asap cair telah digunakan untuk pengawetan dan sumber citarasa pada daging dan ikan. Dengan penggunaan asap cair ini mempunyai kelebihan bila dibandingkan dengan pengasapan konvensional, misalnya biaya lebih murah dan tidak mengandung komponen berbahaya seperti hidrikarbon polisiklis aromatis (PAHs) (Martinez et al., 2005).

Menurut Pszczola (1995), asap cair mempunyai berbagai sifat fungsional. Fungsi utama adalah untuk memberi citarasa dan warna yang diinginkan pada produk asapan yang diperankan oleh senyawa fenol dan karbonil. Fungsi lainnya adalah untuk pengawetan karena kandungan senyawa fenol dan asam yang berperan sebagai antioksidan dan antimikrobia. Oleh sebab itu, asap cair banyak digunakan sebagai zat antimikrobia dan antioksidan dalam bidang pangan.

Dalam penelitian ini dilihat perubahan kimia yang terjadi pada telur asin rasa asap selama proses perendaman dalam larutan garam dengan penambahan asap cair. Selain itu juga dilakukan pengujian sensoris untuk melihat kesukaan panelis terhadap telur asin rasa asap.

\section{METODE PENELITIAN}

\section{Bahan}

Bahan utama dalam penelitian ini adalah telur itik. Telur itik diperoleh langsung dari peternak itik di daerah Malangan, Umbulharjo, Yogyakarta. Spesifikasi telur yang digunakan adalah berumur 1-3 hari setelah itik bertelur, kulit telur utuh tidak retak sama sekali.

Bahan lain adalah garam, asap cair dan air. Garam yang digunakan adalah garam balok beriodium yang diperoleh dari pasar Giwangan, Yogyakarta. Asap cair yang digunakan adalah asap cair yang telah mengalami redistilasi (redistilat asap cair) dan diperoleh dari Laboratorium Rekayasa Proses Pengolahan Fakultas Teknologi Pertanian, Universitas Gadjah Mada.

\section{Tahapan Penelitian}

\section{Pembuatan Telur Asin Rasa Asap}

Pembuatan telur asin ini diawali dengan pembuatan larutan garam $30 \%$ dalam air mendidih. Untuk membuat 10 butir telur asin maka digunakan air 1 liter dan garam $0,3 \mathrm{~kg}$. Telur yang telah sesuai dengan spesifikasi dicuci bersih kemudian dimasukkan ke dalam toples yang telah berisi larutan garam 30\% dengan variasi konsentrasi asap cair $0 \%, 0,5 \%$, dan $1 \%$ $(\mathrm{v} / \mathrm{v})$ dan direndam dalam larutan garam selama 8, 10, dan 12 hari. Telur asin ini akan digunakan untuk analisa kimia dan untuk pengujian sensoris.

\section{Analisa Kimia}

Pada hari peredaman ke- 8,10 , dan 12 untuk masing-masing konsentrasi asap cair, 
telur diambil. Kemudian dilakukan perebusan selama 15 menit. Telur asin yang telah direbus tersebut dianalisa kadar air, kadar protein, dan kadar garam pada bagian putih dan pada bagian kuningnya secara terpisah. Untuk analisa kadar lemak hanya pada bagian kuningnya saja yang dianalisa. Analisa kadar air menggunakan metode termogravimetri (AOAC, 1990), analisa kadar protein menggunakan metode mikrokjeldahl (AOAC, 1990), analisa kadar garam menggunakan metode Argentometri (Sudarmadji dkk.,1983), dan analisa kadar lemak menggunakan metode soxlet (AOAC, 1990). Analisa kimia juga dilakukan pada telur itik yang tidak direndam dalam larutan garam dengan terlebih dahulu direbus selama 15 menit.

\section{Pengujian Sensoris}

Pengujian sensoris dilakukan untuk mengetahui tingkat penerimaan panelis dan untuk mengetahui apakah terdapat beda nyata dari masing-masing sampel dengan menggunakan uji kesukaan. Panelis diminta untuk menilai sampel berdasarkan kesukaannya, menurut skala nilai yang sudah disediakan (Kartika dkk., 1988). Atribut mutu yang harus dinilai adalah rasa asap, aroma asap, warna, tekstur, dan keseluruhan. Skala nilai yang digunakan antara 1 sampai dengan 5 dengan skala nilai 1 yang berarti panelis sangat tidak suka dan skala nilai 5 yang berarti panelis sangat suka terhadap sampel produk .

\section{Rancangan Penelitian}

$\begin{array}{ccc}\text { Rancangan } & \text { penelitian } & \text { yang } \\ \text { digunakan adalah } & \text { Rancangan } & \text { Acak }\end{array}$ Sempurna dengan variabel yang berpengaruh adalah konsentrasi asap cair dan lama perendaman. Data yang diperoleh dianalisa dengan analisa varian (ANOVA) dan dilanjutkan dengan DMRT (Duncan Multiple Range Test) bila ada perbedaan nyata.

\section{HASIL DAN PEMBAHASAN}

\section{Kadar Air}

Hasil analisa kadar air telur asin rebus untuk bagian kuning telur dan putih telur pada berbagai konsentrasi asap cair $(0 \%, 0,5 \%, 1 \%)$ dan lama perendaman $(8,10,12$ hari) dapat dilihat pada Tabel 1 dan Tabel 2.

Tabel 1. Kadar air telur asin rebus (kuning telur) pada berbagai konsentrasi asap cair $(0 \%, 0,5 \%, 1 \%)$ dan lama perendaman $(8,10,12$ hari $)$

\begin{tabular}{ccccc}
\hline Konsentrasi & \multicolumn{4}{c}{ Kadar air (\%) } \\
\cline { 2 - 5 } asap cair (\%) & hari ke- & hari ke- & hari ke- & hari ke- \\
& 0 & 8 & 10 & 12 \\
\hline 0 & $45,53^{\mathrm{c}}$ & $31,91^{\mathrm{ab}}$ & $30,42^{\mathrm{a}}$ & $30,23^{\mathrm{a}}$ \\
0,5 & $45,53^{\mathrm{c}}$ & $34,45^{\mathrm{ab}}$ & $32,24^{\mathrm{ab}}$ & $29,87^{\mathrm{a}}$ \\
1 & $45,53^{\mathrm{c}}$ & $34,00^{\mathrm{ab}}$ & $32,86^{\mathrm{ab}}$ & $32,86^{\mathrm{ab}}$ \\
\hline Keterangan : & Tanda superscript dengan huruf yang \\
tidak sama dalam satu kolom dan dalam \\
satu baris & menunjukkan hasil yang \\
berbeda nyata $(\alpha=5 \%)$.
\end{tabular}

Tabel 2. Kadar air telur asin rebus (putih telur) pada berbagai konsentrasi asap cair $(0 \%, 0,5 \%, 1 \%)$ dan lama perendaman $(8,10,12$ hari $)$

\begin{tabular}{ccccc}
\hline Konsentrasi & \multicolumn{4}{c}{ Kadar air $(\%)$} \\
\cline { 2 - 5 } asap cair & hari & hari ke- & hari ke- & hari ke- \\
$(\%)$ & ke-0 & 8 & 10 & 12 \\
\hline 0 & $87,94^{\mathrm{d}}$ & $85,90^{\mathrm{bc}}$ & $85,72^{\mathrm{b}}$ & $85,96^{\mathrm{bc}}$ \\
0,5 & $87,94^{\mathrm{d}}$ & $85,70^{\mathrm{b}}$ & $86,40^{\mathrm{c}}$ & $84,33^{\mathrm{a}}$ \\
1 & $87,94^{\mathrm{d}}$ & $86,47^{\mathrm{c}}$ & $85,87^{\mathrm{bc}}$ & $86,32^{\mathrm{bc}}$ \\
\hline
\end{tabular}

Keterangan : Tanda superscript dengan huruf yang tidak sama dalam satu kolom dan dalam satu baris menunjukkan hasil yang berbeda nyata $(\alpha=5 \%)$.

Kadar air telur, baik pada kuning telur maupun pada putih telur mengalami penurunan selama proses perendaman, terlihat pada Tabel 1 dan Tabel 2. Penurunan kadar air ini disebabkan oleh adanya garam yang menarik air keluar dari telur dan digantikan oleh garam tersebut. Selama proses perendaman, air bermigrasi dari kuning telur menuju putih telur kemudian menuju lingkungan melalui pori pori yang terdapat pada kulit telur (Kaewmanee et al., 2008). Penurunan kadar air paling optimum terjadi pada hari ke-8, setelah itu hanya terjadi sedikit penurunan kadar air.

Kadar air telur asin rasa asap pada bagian kuning (Tabel 1) tidak berbeda nyata dengan telur asin (tanpa asap). Akan tetapi kadar air telur asin rasa asap pada bagian putih lebih tinggi dari telur asin (tanpa asap). Hal ini dikarenakan turunan fenol yang merupakan salah satu komponen utama asap 
cair dapat membentuk ikatan hidrogen dalam air yang dapat meningkatkan kapasitas pengikatan air pada bahan (Martinez et al., 2003).

Tabel 3. Kadar garam telur asin rebus (kuning telur) pada berbagai konsentrasi asap cair $(0 \%, 0,5 \%, 1 \%)$ dan lama perendaman $(8,10,12$ hari $)$

\begin{tabular}{ccccc}
\hline \multirow{2}{*}{$\begin{array}{c}\text { Konsentrasi } \\
\text { asap cair }\end{array}$} & \multicolumn{4}{c}{ Kadar garam (\%) } \\
\cline { 2 - 5 }$(\%)$ & hari & hari ke- & hari & hari \\
& ke 0 & 8 & ke-10 & ke-12 \\
\hline 0 & $0,24^{\mathrm{a}}$ & $0,44^{\mathrm{b}}$ & $0,55^{\mathrm{c}}$ & $0,91^{\mathrm{e}}$ \\
0,5 & $0,24^{\mathrm{a}}$ & $0,49^{\mathrm{b}}$ & $0,46^{\mathrm{b}}$ & $0,70^{\mathrm{d}}$ \\
1 & $0,24^{\mathrm{a}}$ & $0,45^{\mathrm{b}}$ & $0,48^{\mathrm{b}}$ & $0,94^{\mathrm{e}}$ \\
\hline
\end{tabular}

Keterangan : Tanda superscript dengan huruf yang tidak sama dalam satu kolom dan dalam satu baris menunjukkan hasil yang berbeda nyata $(\alpha=5 \%)$.

Tabel 4. Kadar garam telur asin rebus (putih telur) pada berbagai konsentrasi asap cair $(0 \%, 0,5 \%, 1 \%)$ dan lama perendaman $(8,10,12$ hari $)$

\begin{tabular}{ccccc}
\hline Konsentrasi & \multicolumn{4}{c}{ Kadar garam (\%) } \\
\cline { 2 - 5 } asap cair (\%) & $\begin{array}{c}\text { hari } \\
\text { ke-0 }\end{array}$ & $\begin{array}{c}\text { hari } \\
\text { ke- } 8\end{array}$ & $\begin{array}{c}\text { hari } \\
\text { ke-10 }\end{array}$ & $\begin{array}{c}\text { hari } \\
\text { ke-12 }\end{array}$ \\
\hline 0 & $0,18^{\mathrm{a}}$ & $2,58^{\mathrm{c}}$ & $3,14^{\mathrm{f}}$ & $3,41^{\mathrm{g}}$ \\
0,5 & $0,18^{\mathrm{a}}$ & $2,56^{\mathrm{c}}$ & $2,75^{\mathrm{d}}$ & $2,27^{\mathrm{b}}$ \\
1 & $0,18^{\mathrm{a}}$ & $2,56^{\mathrm{c}}$ & $2,41^{\mathrm{b}}$ & $2,93^{\mathrm{e}}$ \\
\hline
\end{tabular}

Keterangan : Tanda superscript dengan huruf yang tidak sama dalam satu kolom dan dalam satu baris menunjukkan hasil yang berbeda nyata $(\alpha=5 \%)$.

\section{Kadar Garam}

Kadar garam pada kuning telur maupun pada putih telur mengalami kenaikan dengan semakin lamanya waktu perendaman (Tabel 3 dan Tabel 4). Selama proses perendaman, garam akan masuk ke dalam telur melalui proses osmosis sehingga kadar garam pada telur akan naik. Kenaikan kadar garam ini akan mempengaruhi terbentuknya rasa asin pada telur. Kenaikan kadar garam pada putih telur lebih cepat daripada pada kuning telur. Hal ini terlihat dari kadar garam yang lebih tinggi pada putih telur setelah proses perendaman. Hal ini disebabkan karena kuning telur mempunyai kandungan lemak yang tinggi. Kandungan lemak yang tinggi ini akan menghambat masuknya garam ke dalam kuning telur (Kaewmanee et al.,2008).
Kadar garam telur asin rasa asap pada bagian putih lebih rendah dari telur asin (tanpa asap). Dengan adanya penambahan asap cair kadar garam akan mengalami penurunan. Hal ini berhubungan erat dengan kadar air pada telur. Dengan penambahan asap cair kadar air telur mengalami peningkatan sehingga garam yang masuk ke dalam telur lebih sedikit atau mengalami penurunan.

\section{Kadar Lemak}

Kandungan lemak pada kuning telur sangat tinggi, yaitu $61,1188(\% \mathrm{db})$ atau 33,2933 (\% wb). Menurut Stadelman dan Cotterill (1977) kandungan lemak pada kuning telur antara 32-36\%. Sedangkan kandungan lemak pada putih telur bisa diabaikan. Dari Tabel 5 terlihat bahwa tidak ada beda nyata antara kandungan lemak di dalam kuning telur dengan lama perendaman maupun dengan konsentrasi asap cair yang berbada. Ini menunjukkan bahwa proses perendaman telur dalam larutan garam maupun penambahan asap cair tidak berpengaruh terhadap kandungan lemak pada kuning telur.

Tabel 5. Kadar lemak telur asin rebus (kuning telur) pada berbagai konsentrasi asap cair $(0 \%, 0,5 \%, 1 \%)$ dan lama perendaman $(8,10,12$ hari)

\begin{tabular}{ccccc}
\hline Konsentrasi & \multicolumn{4}{c}{ Kadar lemak (\% db) } \\
\cline { 2 - 5 } $\begin{array}{c}\text { asap cair } \\
(\%)\end{array}$ & Hari & Hari & Hari & Hari \\
ke-0 & ke-8 & ke-10 & ke-12 \\
\hline 0 & $61,12^{\mathrm{a}}$ & $67,97^{\mathrm{a}}$ & $68,41^{\mathrm{a}}$ & $69,61^{\mathrm{a}}$ \\
0,5 & $61,12^{\mathrm{a}}$ & $58,50^{\mathrm{a}}$ & $72,43^{\mathrm{a}}$ & $66,64^{\mathrm{a}}$ \\
1 & $61,12^{\mathrm{a}}$ & $64,27^{\mathrm{a}}$ & $66,65^{\mathrm{a}}$ & $67,40^{\mathrm{a}}$ \\
\hline
\end{tabular}

Keterangan : Tanda superscript dengan huruf yang tidak sama dalam satu kolom dan dalam satu baris menunjukkan hasil yang berbeda nyata $(\alpha=5 \%)$.

\section{Kadar Protein}

Kadar protein di dalam kuning telur selama perendaman tidak ada perubahan (Tabel 6). Hal ini menunjukkan bahwa proses perendaman telur dalam larutan garam maupun dengan penambahan asap cair tidak berpengaruh terhadap kadar protein pada kuning telur. Akan tetapi pada putih telur terjadi penurunan kadar protein setelah proses perendaman telur dalam larutan garam setelah perendaman hari ke-8 
seperti terlihat pada Tabel 7. Penurunan kadar protein ini terjadi pada telur dengan penambahan asap cair maupun tidak. Hal ini disebabkan oleh larutnya protein selama perendaman karena pada putih telur mempunyai kadar air yang tinggi dan semakin lama perendaman maka semakin banyak pula air yang keluar dari telur. Protein pada putih telur adalah albumin. Menurut Winarno (2002) sifat dari protein albumin adalah larut dalam air dan terkoagulasi oleh panas. Setelah hari perendaman ke-8 kadar protein putih telur tidak mengalami perubahan. Hal ini disebabkan karena setelah hari perendaman ke-8 konsentrasi garam di dalam telur dan di dalam larutan perendam hampir seimbang sehingga perpindahan air dan garam sangat kecil. Dengan demikian albumin yang sifatnya larut air juga tidak berkurang.

Tabel 6. Kadar protein telur asin rebus (kuning telur) pada berbagai konsentrasi asap cair $(0 \%, 0,5 \%, 1 \%)$ dan lama perendaman $(8,10,12$ hari)

\begin{tabular}{ccccc}
\hline Konsentrasi & \multicolumn{4}{c}{ Kadar protein (\%) } \\
\cline { 2 - 5 } asap cair & hari & hari & hari ke- & hari \\
$(\%)$ & ke-0 & ke-8 & 10 & ke-12 \\
\hline 0 & $28,27^{\mathrm{b}}$ & $28,31^{\mathrm{b}}$ & $31,07^{\mathrm{b}}$ & $28,77^{\mathrm{b}}$ \\
0,5 & $28,27^{\mathrm{b}}$ & $29,09^{\mathrm{b}}$ & $29,07^{\mathrm{b}}$ & $28,30^{\mathrm{b}}$ \\
1 & $28,27^{\mathrm{b}}$ & $28.42^{\mathrm{a}}$ & $30,46^{\mathrm{b}}$ & $30,06^{\mathrm{b}}$ \\
\hline
\end{tabular}

Keterangan : Tanda superscript dengan huruf yang tidak sama dalam satu kolom dan dalam satu baris menunjukkan hasil yang berbeda nyata $(\alpha=5 \%)$.

Tabel 7. Kadar protein telur asin rebus (putih telur) pada berbagai konsentrasi asap cair $(0 \%, 0,5 \%, 1 \%)$ dan lama perendaman $(8,10,12$ hari)

\begin{tabular}{ccccc}
\hline Konsentrasi & \multicolumn{4}{c}{ Kadar protein (\%) } \\
\cline { 2 - 5 } asap cair & hari & hari & hari & hari ke- \\
$(\%)$ & ke-0 & ke- 8 & ke-10 & 12 \\
\hline 0 & $82,37^{\mathrm{c}}$ & $62.41^{\mathrm{a}}$ & $67,63^{\mathrm{a}}$ & $62,56^{\mathrm{a}}$ \\
0,5 & $82,37^{\mathrm{c}}$ & $65.79^{\mathrm{a}}$ & $65,59^{\mathrm{a}}$ & $64,90^{\mathrm{a}}$ \\
1 & $82,37^{\mathrm{c}}$ & $63,73^{\mathrm{a}}$ & $64,42^{\mathrm{a}}$ & $66,89^{\mathrm{ab}}$ \\
\hline
\end{tabular}

Keterangan : Tanda superscript dengan huruf yang tidak sama dalam satu kolom dan dalam satu baris menunjukkan hasil yang berbeda nyata $(\alpha=5 \%)$.

Sedangkan dengan penambahan asap cair maupun tidak, kadar protein putih telur tidak berbeda nyata sehingga bisa dikatakan bahwa penambahan asap cair tidak berpengaruh terhadap kadar protein pada putih telur.

\section{Pengujian Sensoris}

Rasa merupakan salah satu faktor penentu mutu pada produk asapan karena akan berpengaruh terhadap penerimaan konsumen. Dengan semakin tinggi konsentrasi asap cair maka flavor asap yang terbentuk juga semakin tinggi. Demikian juga dengan semakin lamanya waktu perendaman maka semakin tinggi pula flavor asap yang terbentuk karena akan semakin banyak komponen fenol yang masuk ke dalam telur.

Kesukaan panelis terhadap rasa telur asin dengan konsentrasi asap cair $0,5 \%$ dan lama perendaman 8 hari dengan telur asin yang lain terdapat perbedaan yang nyata (Tabel 8). Telur asin ini mendapatkan nilai tertinggi yaitu 3,95. Dengan demikian dapat dikatakan bahwa telur asin dengan konsentrasi asap cair $0,5 \%$ dengan lama perendaman 8 hari merupakan telur asin dengan rasa asap yang paling disukai oleh panelis. Sedangkan untuk variasi telur asin yang lain tidak saling beda nyata kecuali untuk telur asin dengan konsentrasi asap cair $1 \%$ dan lama perendaman 8 hari. Telur asin tersebut mendapat nilai terendah yaitu 2,55. Nilai yang diperoleh telur asin dengan variasi konsentrasi asap cair dan lama perendaman $0 \%$, 8hari; $0,5 \%, 8$ hari ; $1 \%, 8$ hari; $0 \%, 10$ hari; $0 \%, 12$ hari; 0,5\%,12 hari; dan 1\%, 12 hari adalah antara 3,1 hingga 3,95 yang berarti panelis dapat menerima rasa asap dari telur asin tersebut. Sedangkan untuk telur asin dengan variasi konsentrasi asap cair dan lama perendaman 0,5\%,10 hari dan 1\%, 10 hari mendapat nilai 2,55 dan 2,95 yang berarti panelis menolak rasa asap pada telur asin tersebut.

Rasa asap yag terbentuk pada produk diakibatkan oleh adanya komponen fenol dari asap cair. Menurut Daun (1979), senyawa fenol yang berperan dalam pembentukan flavor asap adalah guaikol, 4-metil guaikol, dan 2,6-dimetoksi fenol. Guaikol memerikan rasa asap sementara siringol memberi aroma asap.

Aroma asap dengan konsetrasi asap cair yang lebih tinggi dan lama perendaman 
Tabel 8. Uji kesukaan telur asin rasa asap dengan atribut mutu rasa asap, aroma asap, warna, tekstur, dan keseluruhan

\begin{tabular}{|c|c|c|c|c|c|}
\hline Sampel & Rasa & Aroma & Warna & Tekstur & Keseluruhan \\
\hline $0 \%, 8$ hari & $3,25^{b}$ & $3,25^{a b}$ & $3,30^{b}$ & $3,50^{\mathrm{a}}$ & $3,35^{b c}$ \\
\hline $0,5 \%, 8$ hari & $3,95^{\mathrm{c}}$ & $3,55^{\mathrm{b}}$ & $3,70^{\mathrm{b}}$ & $3,65^{\mathrm{a}}$ & $3,95^{\mathrm{d}}$ \\
\hline $1 \%, 8$ hari & $3,25^{\mathrm{b}}$ & $3,10^{a b}$ & $3,55^{\mathrm{b}}$ & $3,45^{a}$ & $3,40^{\mathrm{c}}$ \\
\hline $0 \%, 10$ hari & $3,10^{a b}$ & $3,10^{\mathrm{ab}}$ & $2,30^{\mathrm{a}}$ & $3,25^{\mathrm{a}}$ & $2,70^{\mathrm{a}}$ \\
\hline $0,5 \%, 10$ hari & $2,95^{\mathrm{ab}}$ & $2,85^{\mathrm{a}}$ & $1,90^{\mathrm{a}}$ & $3,15^{a}$ & $2,80^{a b}$ \\
\hline $1 \%, 10$ hari & $2,55^{\mathrm{a}}$ & $2,80^{\mathrm{a}}$ & $2,05^{\mathrm{a}}$ & $3,00^{\mathrm{a}}$ & $2,40^{\mathrm{a}}$ \\
\hline $0 \%, 12$ hari & $3,10^{a b}$ & $3,20^{a b}$ & $3,45^{b}$ & $3,45^{\mathrm{a}}$ & $3,30^{\mathrm{bc}}$ \\
\hline $0,5 \%, 12$ hari & $3,15^{a b}$ & $3,15^{a b}$ & $3,40^{\mathrm{b}}$ & $3,30^{\mathrm{a}}$ & $3,35^{\mathrm{bc}}$ \\
\hline $1 \%, 12$ hari & $3,30^{\mathrm{b}}$ & $3,15^{\mathrm{ab}}$ & $3,50^{\mathrm{b}}$ & $3,45^{\mathrm{a}}$ & $3,30^{b c}$ \\
\hline
\end{tabular}

Keterangan : Tanda superscript dengan huruf yang tidak sama dalam satu kolom, menunjukkan hasil yang berbeda nyata $(\alpha=5 \%)$.

Uji Kesukaan :(1) Sangat Tidak Suka (2) Tidak Suka (3) Netral (4) Suka (5) Sangat Suka

yang lebih lama akan memberikan aroma asap yang lebih kuat pula pada telur asin rasa asap. Dari Tabel 8 terlihat bahwa tidak ada beda nyata kesukaan panelis terhadap aroma dari semua variasi sampel. Nilai yang diperoleh telur asin dengan variasi konsentrasi asap cair dan lama perendaman $0 \%, 8$ hari; $0,5 \%, 8$ hari ; $1 \%, 8$ hari; $0 \%, 10$ hari; $0 \%, 12$ hari; $0,5 \%, 12$ hari; dan $1 \%, 12$ hari adalah antara 3,1 hingga 3,55 yang berarti panelis dapat menerima aroma asap dari telur asin tersebut. Sedangkan untuk telur asin dengan variasi konsentrasi asap cair dan lama perendaman $0,5 \%, 10$ hari dan $1 \%, 10$ hari mendapat nilai 2,85 dan 2,80 yang berarti panelis menolak aroma asap telur asin tersebut. Menurut Girard (1992), aroma asap yang terbentuk sebagian besar dipengaruhi oleh adanya senyawa fenol dan karbonil serta sebagian kecil juga dipengaruhi oleh asam.

Pada pengujian atribut warna, panelis diminta menilai bagian kuning telur. Dari Tabel 8 terlihat bahwa tidak ada beda nyata kesukaan panelis terhadap warna antar variasi telur asin kecuali pada telur asin dengan variasi konsentrasi asap cair dan lama perendaman $0 \%, 10$ hari; $0,5 \%, 10$ hari ; $1 \%, 10$ hari. Nilai yang diperoleh telur asin dengan variasi konsentrasi asap cair dan lama perendaman $0 \%$,8hari; $0,5 \%, 8$ hari ; $1 \%, 8$ hari; $0 \%, 12$ hari; $0,5 \%, 12$ hari; dan
$1 \%, 12$ hari adalah antara 3,3 hingga 3,70 yang berarti panelis dapat menerima warna dari telur asin tersebut. Sedangkan untuk telur asin dengan variasi konsentrasi asap cair dan lama perendaman $0 \%, 10$ hari; $0,5 \%, 10$ hari dan $1 \%$ panelis menolak telur asin sampel tersebut.

Warna dari kuning telur asin adalah orange. Terbentuknya warna orange ini disebabkan karena kuning telur kehilangan air selama proses perendaman dalam larutan garam. Kehilangan air dari telur menyebabkan perubahan warna pada kuning telur (Lai et al., 1999). Dengan demikian perendaman dengan larutan garam menyebabkan kadar air telur menurun sehingga warna orange pada kuning telur semakin pekat. Kenampakan pada kuning telur asin berminyak. Hal ini berhubungan dengan hilangnya air dari kuning telur dan digantikannya oleh garam. Butir-butir garam dalam kuning telur berikatan dengan lipoprotein sehingga ikatan lipoprotein rusak dan lemak keluar (Kaewmanee et al., 2008).

Dari Tabel 8 terlihat bahwa tidak ada perbedaan nyata kesukaan panelis terhadap tekstur dari semua variasi sampel telur asin. Nilai yang diperoleh oleh semua sampel telur asin adalah antara 3,0 sampai dengan 3.65 yang berarti panelis dapat menerima tekstur dari semua sampel telur asin. Menurut Kaewmanee et al (2008) 
karakteristik telur asin yang disukai oleh konsumen adalah telur asin yang berwarna orange pada bagian kuning telur, berminyak pada bagian kuning telur, dan mempunyai tekstur gritty. Terbentuknya tekstur gritty ini disebabkan karena hilangnya air dari telur.

Kesukaan panelis secara keseluruhan merupakan kombinasi seluruh atribut sensoris yang dimiliki oleh telur asin rasa asap. Dari Tabel 8 diketahui bahwa variasi yang paling disukai panelis adalah telur asin dengan konsentrasi asap cair 0,5\% dengan lama perendaman 8 hari karena mendapat nilai yang tertinggi yaitu 3,95. Kesukaan panelis terhadap telur asin ini beda nyata dengan yang lain. Sedangkan untuk sampel yang lain tidak saling beda nyata kecuali dengan sampel dengan variasi konsentrasi asap cair dan lama perendaman $0 \%, 10$ hari; $0,5 \%, 10$ hari; $1 \%, 10$ hari. Nilai yang diperoleh telur asin dengan variasi konsentrasi asap cair dan lama perendaman $0 \%$, 8hari; $0,5 \%, 8$ hari ; $1 \%, 8$ hari; $0 \%$, 12 hari; $0,5 \%, 12$ hari dan 1\%, 12 hari adalah antara 3,30 hingga 3,95 yang berarti panelis dapat menerima secara keseluruhan dari telur asin tersebut. Sedangkan untuk telur asin dengan variasi konsentrasi asap cair dan lama perendaman $0 \%, 10$ hari; $0,5 \%, 10$ hari dan $1 \%, 10$ hari mendapat nilai 2,$7 ; 2,8$; dan 2,40 yang berarti panelis menolak secara keseluruhan dari telur asin tersebut.

\section{KESIMPULAN}

Selama proses perendaman telur dalam larutan garam dengan penambahan asap cair terjadi perubahan kadar air, kadar garam, dan kadar protein pada telur. Akan tetapi kadar lemak tidak mengalami perubahan. Semakin lama waktu perendaman terjadi penurunan kadar air pada kuning maupun pada putih telur dan penurunan kadar protein pada putih telur. Sedangkan kadar garam pada kuning maupun pada putih telur mengalami kenaikan. Kadar air pada putih telur asin asap lebih tinggi daripada telur asin (tanpa asap) dan kadar garam pada putih telur asin asap lebih rendah daripada telur asin (tanpa asap). Kadar lemak dan kadar protein tidak berbeda nyata antara telur asin asap dan telur asin (tanpa asap). Telur asin yang dibuat dengan penambahan asap cair dengan konsentrasi $0,5 \%$ dan lama perendaman 8 hari merupakan telur asin rasa asap yang paling disukai panelis.

\section{DAFTAR PUSTAKA}

Anonim (1981). Daftar Komposisi Bahan Makanan. Direktorat Gizi Depkes RI. Bhatara Karya Aksara. Jakarta.

Anonim (1990). Association of Official Analytical Chemistry Official Method of Analysis. $18^{\text {th }}$ editor. Benjamin Franklin. Washington D.C.

Anonim (2000). Telur Asin. http://www.warintek.ristek.go.id/panga n_kesehatan/pangan/.../telur_asin.pdf . [15 Januari 2009]

Daun, H. (1979). Interaction of Wood Smoke Component and Food. Journal Food Tech. 35 (5) : $66-70$

Girard, J.P. (1992). Technology of Meat and Meat Product Smoking. Ellis Harwood. New York.

Gorbatov, $\quad$ V.M.,
Volovinskaya,V.P.,
Cyaskovkaya,Y.N., Bazarova, K.I.,
Khlamova,R.I., and Yakavlova,G.Y.
(1971). Liquid Smoke For Use in
Cured Meat. Journal Food Tech 25:
71-77

Kaewmanee,T.,Benjakul,S., and Visessanguan,W. (2008). Changes in Chemical Composition, Physical Properties and Microstructure of Duck Egg as Influenced by Salting. Journal Food Chemistry 112(2008) 560-569

Kartika,B., Hastuti,P., Supartono,W. (1988). Pedoman Uji Inderawi Bahan Pangan. PAU Pangan dan Gizi. Yogyakarta.

Lai,K.M., Chi, S.P., and Ko, W.C. (1999). Changes in Yolk States of Duck Egg During Long-Term Brining. Journal Agric. Food Chem. 47(2):733-736.

Marssy,R. (2007). Telur Asin, Asin Tapi Berkalsium 
http://radmarssy.wordpress.com.

Januari 2009]

Martinez, O, J. Salmerón , Guillén,M.D., and Casas,C. (2003). Texture profile analysis of meat products treated with commercial liquid smoke flavourings. Journal Food Control 15 (6) : 457-461

Pszczola, D.E. (1995). Tour Highlights Production and Users of Smoke Based Flavors. Journal Food Tech.(1) : 70-74

Sarwono,B. (1986). Telur : Pengawetan dan Manfatnya. Jakarta: PT Penebar. Swadaya.

Stadelmann,W.J dan Cotterill,O.J. (1973). Egg Science and Technology. The AVI Publishing Company Inc. Wesport, Connecticut

Sudarmadji,S., Haryono,B., Suhardi. (1983). Analisa Bahan Makanan dan Pertanian. Penerbit Liberty, Yogyakarta

Winarno,F.G. (2002). Kimia Pangan dan Gizi. Jakarta : Gramedia. 